\title{
ANALISIS PENGARUH INFRASTRUKTUR, TINGKAT KEMISKINAN DAN INDEKS PEMBANGUNAN MANUSIA TERHADAP PERTUMBUHAN EKONOMI PROVINSI BALI 2015-2020
}

\section{Risthi Khoirunnisa Wadana, Whinarko Juli Prijanto}

Universitas Tidar Magelang Jawa Tengah, Indonesia

Email: risthiwdn@gmail.com, juliprijanto@yahoo.com

\section{Diterima \\ 1 Juni 2021 \\ Direvisi \\ 10 Juni 2021 \\ Disetujui \\ 20 Juni 2021}

INFO ARTIKEL

\section{Keywords:}

Infrastructure; Human

Development Index; Poverty and Economic Growth

\begin{abstract}
Economic growth is an important pillar in regional development. Economic growth is one of the indicators to measure development outcomes and is an important indicator to determine the direction of future development. If the infrastructure is not good, development will not run smoothly. If infrastructure is weak, the economic operations of a country or region will be inadequate. And humans are not only the object of development, but are also expected to be the main body, making useful contributions to the progress of an area from a macro perspective. The development of the rate of economic growth in the Province of Bali during the 2015-2020 period experienced fluctuating changes. Therefore, this study aims to determine the effect of economic variables on the economic growth of districts/cities in the province of Bali. The type of data in this study is panel data which is a combination of time series data from 2015-2020 and cross section data from nine districts/cities in Bali Province. By using Eviews $X$ software, panel data regression analysis in this study uses the Fixed Effect Model approach, based on the results of the study it was obtained that partially road infrastructure variables have a positive and significant influence on the rate of economic growth. Meanwhile, the variable of the poor population partially has a positive but not significant effect on the rate of economic growth. And partially the Human Development Index (HDI) variable has a negative and significant influence on the rate of economic growth.
\end{abstract}

\footnotetext{
ABSTRAK

Pertumbuhan ekonomi merupakan pilar penting dalam pembangunan daerah. Pertumbuhan ekonomi merupakan salah satu indikator untuk mengukur hasil pembangunan dan merupakan indikator penting untuk menentukan arah pembangunan ke depan. Jika infrastruktur tidak bagus, pembangunan tidak akan berjalan mulus. Jika infrastruktur lemah, operasi ekonomi suatu negara atau wilayah akan menjadi tidak memadai. Dan manusia tidak hanya menjadi
}

\begin{tabular}{|c|c|}
\hline How to cite: & $\begin{array}{l}\text { Wadana Risthi Khoirunnisa, Whinarko Juli Prijanto (2021) Analisis Pengaruh Infrastruktur, Tingkat } \\
\text { Kemiskinan dan Indeks Pembangunan Manusia terhadap Pertumbuhan Ekonomi Provinsi Bali 2015- }\end{array}$ \\
\hline & $\begin{array}{l}\text { 2020. Jurnal Syntax Ttansformation } \\
\text { transformation.v2i6.303 }\end{array}$ \\
\hline E-ISSN: & $2721-2769$ \\
\hline Published by: & Ridwan Institute \\
\hline
\end{tabular}


objek pembangunan, tetapi juga diharapkan menjadi tubuh utama, memberikan kontribusi yang bermanfaat bagi kemajuan suatu daerah dari perspektif makro. Perkembangan laju pertumbuhan ekonomi di Provinsi Bali selama periode 2015-2020 mengalami perubahan yang fluktuatif. Oleh Karena itu, penelitian ini bertujuan untuk mengetahui pengaruh variabel-variabel ekonomi terhadap pertumbuhan ekonomi kabupaten/kota di Provinsi Bali. Jenis data dalam penelitian ini adalah data panel yang merupakan gabungan dari data time series dari tahun 20152020 dan data cross section dari sembilan kabupaten/kota di Provinsi Bali. Dengan menggunakan software Eviews $X$ analisis regresi data panel dalam penelitian ini menggunakan pendekatan Fixed Effect Model, berdasarkan hasil penelitian diperoleh bahwa secara parsial variabel infrastruktur jalan memiliki pengaruh positif dan signifikan terhadap laju pertumbuhan ekonomi. Sedangkan

Kata Kunci:

Infrastruktur; Indeks

Pembangunan Manusia;

Kemiskinan dan Pertumbuhan

Ekonomi untuk variabel penduduk miskin secara parsial memiliki pengaruh yang positif namun tidak signifikan terhadap laju pertumbuhan ekonomi. Serta secara parsial variabel Indeks Pembangunan Manusia (IPM) memiliki pengaruh negatif dan signifikan terhadap laju pertumbuhan ekonomi.

\section{Pendahuluan}

Pertumbuhan ekonomi merupakan salah satu indikator terpenting untuk mengevaluasi kinerja ekonomi, terutama untuk menganalisis hasil-hasil upaya suatu negara atau regional untuk mencapai pembangunan ekonomi. (Resalawati, 2011) Jika produksi barang dan jasa meningkat dibanding tahun sebelumnya, dapat dikatakan ekonomi mengalami pertumbuhan. Pertumbuhan ekonomi menunjukkan sejauh mana kegiatan ekonomi akan memberikan pendapatan lebih bagi masyarakat dalam kurun waktu tertentu. Pertumbuhan ekonomi diukur dengan Gross Domestic Product (GDP). Parameter pertumbuhan ekonomi dari penyediaan barang dan jasa yang dapat digunakan di dalam negeri, seperti peningkatan jumlah produk industri, peningkatan infrastruktur, penambahan sekolah, peningkatan penyediaan layanan dan peningkatan jumlah ahli bagasi (Mankiw, 2006).
Pembangunan infrastruktur menjadi salah satu indikator yang dapat mendorong maupun menghambat pertumbuhan perekonomian. Jika infrastruktur lemah, operasi ekonomi suatu negara atau regional menjadi tidak memadai (Kustanto, 2020). Beban logistik tinggi, daya saing berkurang dan diskriminatif sosial terjadi. Pembangunan infrastruktur dan kegiatan ekonomi terdapat korelasi antara keduanya karena pembangunan infrastruktur berorientasi pada ekspansi ekonomi melalui efek pengganda. Dengan ekspansi ekonomi, infrastruktur yang ada dapat menyerap besarnya aliran barang dan jasa yang beredar di seluruh perekonomian (Damayanthi, 2008). Infrastruktur dapat mendukung aktivitas ekonomi masyarakat dan kelancaran distribusi aliran barang, maka dapat disimpulkan bahwa infrastruktur merupakan sarana public primer yang menjalankan roda perekonomian nasional, dengan adanya infrastruktur yang memadai akan terselenggara sistem transportasi yang efektif. Infrastruktur yang dapat mendukung 
aktivitas ekonomi masyarakat dan kelancaran distribusi aliran barang salah satunya adalah jalan, jalan merupakan salah satu infrastruktur yang paling sering digunakan untuk suatu wilayah agar pertumbuhan ekonomi meningkat (Iriyena, 2019).

Infrastruktur juga dapat dijadikan mobil penggerak pembangunan nasional dan menjadi konektivitas antar wilayah yang ada di Indonesia. Perbaikan pada sektor infrastruktur tentunya dapat mendorong minat investasi asing dan domestik. Peningkatan pertumbuhan ekonomi Indonesia beberapa tahun terakhir salah satunya ditenggarai karena meningkatnya perhatian pemerintah terhadap investasi infrastruktur. Keberadaan Infrastruktur yang memadai seharunya akan berkontribusi kepada kelancaran produksi maupun distribusi barang dan jasa antar wilayah yang pada akhirnya dapat meningkatkan pertumbuhan ekonomi (Ilham et al., 2021).

Selain infrastruktur, pertumbuhan ekonomi dapat dipengaruhi dengan tingkat Indeks Pembangunan Manusia (IPM). IPM merupakan indikator untuk mengukur kualitas hidup manusia. IPM merupakan gabungan dari 3 dimensi yaitu umur panjang dan hidup sehat, pengetahuan, dan standar hidup layak. Dimana masing-masing dimensi tersebut dihitung nilai indeksnya, kemudian didapat nilai IPM (Prasetyoningrum \& Sukmawati, 2018).

Dimana tingkat indeks pembangunan manusia yang tinggi menjadi salah satu indikator dalam keberhasilan suatu pembangunan (Mirza, 2012). Melalui kemampuan masyarakat untuk dapat berkontribusi lebih banyak dalam meningkatkan produktivitas dan kreativitas baik yang berkaitan dengan kelembagaan maupun teknologi. Indeks Pembangunan Manusia memainkan peran penting dalam perkembangan ekonomi modern karena pembangunan manusia yang baik akan memaksimalkan faktor produksi. Kualitas penduduk yang baik akan memungkinkan adanya inovasi untuk mengembangkan faktor-faktor produksi yang ada. Selain itu, tingginya tingkat pembangunan manusia telah menyebabkan peningkatan jumlah orang sehingga akan meningkatkan tingkat konsumsi. Berbanding terbalik dengan IPM (Susanto, 2013).

Selain infrastruktur dan indeks pembangunan manusia, pertumbuhan ekonomi juga dipengaruhi dengan tingkat kemiskinan. Secara teoritis, upaya pengentasan kemiskinan mensyaratkan adanya pertumbuhan ekonomi yang berkualitas. Pertumbuhan ekonomi yang berkualitas dapat diwujudkan dengan kebijakan perluasan kesempatan kerja (mengurangi tingkat pengangguran) dan memaksimalkan investasi yang produkif di berbagai sektor ekonomi. Menurut teori neo klasik, pertumbuhan ekonomi tergantung pada pertambahan penyediaan faktor-faktor produksi (penduduk, tenaga kerja, dan akumulasi modal) dan tingkat kemajuan teknologi (Ali, 2009). Pembentukan modal menghasilkan kemajuan teknik yang menunjang tercapainya ekonomi produksi skala luas dan meningkatkan spesialisasi, Pembentukan modal memberikan mesin, alat dan perlengkapan bagi tenaga kerja yang semakin meningkat (Jonaidi, 2012).

Rendahnya tingkat kemiskinan menjadi suatu indicator penting dalam keberhasilan pertumbuhan ekonomi dikarenakan rendahnya tingkat kemiskinan berarti terdapat produktivitas yang tinggi pada masyarakat, hal tersebut mengakibatkan tingginya pendapatan yang masyarakat terima. Tingginya pendapatan akan berimplikasi pada rendahnya tabungan dan investasi yang menunjang pertumbuhan ekonomi (Susanto, 2013). 
Bali merupakan provinsi di Indonesia yang memiliki letak astronomis $8^{\circ} 25^{\prime} 23^{\prime \prime} \quad$ Lintang Selatan dan $115^{\circ} 14^{\prime} 55^{\prime \prime}$ Bujur Timur. Luas wilayah Bali mencapai 5.780,06 $\mathrm{km}^{2}$ atau $0,29 \%$ dari luas wilayah Indonesia yang terdiri atas satu kotamadya dan delapan kabupaten, terbagi lagi menjadi 57 kecamatan dan 716 desa/kelurahan, Berdasarkan data dari Badan Pusat Statistik (BPS) Provinsi Bali, perkembangan laju pertumbuhan ekonomi di Provinsi Bali selama periode 2015-2020 mengalami perubahan yang fluktuatif dan mengalami penurunan yang sangat tajam di tahun 2020 sebagaimana yang ditunjukkan pada grafik 1 .

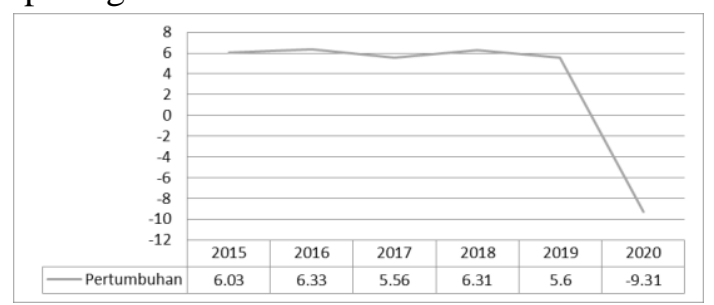

Grafik 1.

\section{Laju Pertumbuhan Ekonomi Provinsi Bali Tahun 2015-2020}

Sumber : Badan Pusat Statisik Provnsi Bali dalam Angka 2015-2020

Perkembangan ekonomi Provinsi Bali periode 2015-2020 mengalami perubahan yang fluktuatif dan mengalami penurunan tajam dari tahun 2019 ke 2020 dimana tahun 2019 menunjukkan 5,6\% dan pada 2020 menunjukkan $-9,31 \%$, faktor yang menjadi penurunan tajam ini disebabkan karena pandemi Covid-19 yang berdampak negatif terhadap perekonomian daerah secara keseluruhan. Bukti ini bisa dilihat dari data BPS Provinsi Bali yang memperlihatkan kategori lapangan usaha akomodasi, makanan dan minuman sebagai penyumbang pertumbuhan ekonomi terbesar justru tumbuh negatif. Begitu pula sektor transportasi dan pergudangan, pengadaan listrik, industri pengolahan dan jasa lainnya, semua terpukul karena Covid-19. Hanya tercatat lapangan usaha informasi dan komunikasi mengalami pertumbuhan positif.

$$
\text { Namun dalam No.SP- }
$$

319/HUM/ROKOM/SET.MARVES/V/2021

Kementerian Koordinator Bidang

Kemaritiman dan Investasi Republik Indonesia menyatakan bahwa meskipun sedang ada dalam masa pandemi, tetapi pembangunan harus tetap berjalan dimana pertumbuhan ekonomi di Provinsi Bali masih mengalami kontraksi yang cukup dalam karena sangat tergantung pada sektor pariwisata. Oleh karena itu, pada masa mendatang Provinsi Bali diupayakan untuk tidak hanya akan fokus ke sektor pariwisata, tetapi juga sektor lain yaitu dengan mendorong percepatan pembangunan infrastruktur di berbagai sektor (Utama, 2020).

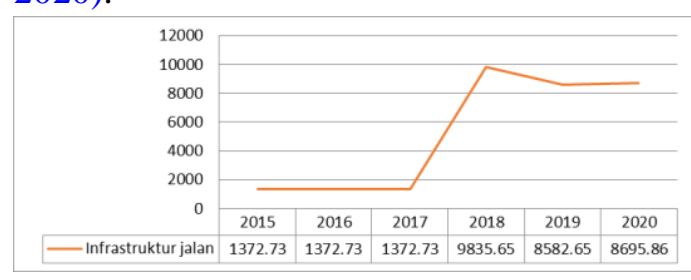

Grafik 2

\section{Perkembangan Panjang Infrastruktur Jalan Provinsi Bali Tahun 2015-2020}

Sumber : Badan Pusat Statisik Provnsi Bali dalam Angka 2015-2020

Dalam hal infrastruktur jalan raya, panjang jalan di Provinsi Bali yang berstatus jalan provinsi mengalami peningkatan drastis dari tahun 2017 yang menunjukkan angka $1372.73 \mathrm{~km}$ menjadi $9835.65 \mathrm{~km}$ pada tahun 2018. Peningkatan sebesar $8462.92 \mathrm{~km}$ disebabkan karena jalan merupakan sarana penting penunjang pembangunan antar daerah. Kemudahan yang ditimbulkan oleh ketersediaan jalan raya secara otomatis akan berdampak positif bagi kelangsungan transaksi ekonomi antar daerah/kota di Provinsi Bali. Sistem jalan yang baik memberikan keunggulan kompetitif bagi suatu negara atau wilayah, 
memungkinkannya bersaing dalam pemasaran produk, pengembangan industri, distribusi penduduk dan pertumbuhan pendapatan. Jaringan jalan yang terbatas akan menghambat pertumbuhan wilayah, sehingga mengganggu kegiatan ekonomi dan menyebabkan harga komoditas menjadi lebih tinggi.

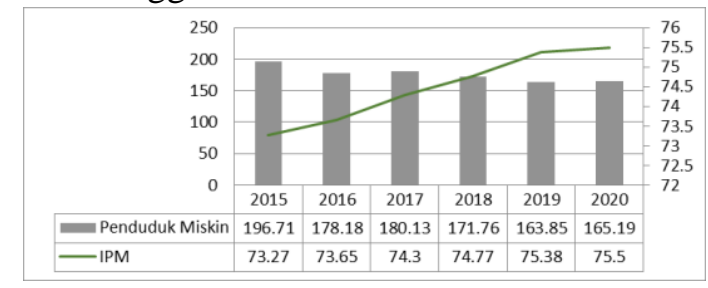

Grafik 3

Perkembangan Kemiskinan dan IPM

Provinsi Bali Tahun 2015-2020

Sumber : Badan Pusat Statisik Provinsi Bali dalam Angka 2015-2020

Kondisi kesejahteraan di Provinsi Bali secara umum terjaga, Indeks Pembangunan Manusia (IPM) yang merupakan indikator untuk mengukur keberhasilan dalam upaya membangun kualitas hidup manusia menjelaskan kondisi penduduk saat mengakses hasil pembangunan dalam memperoleh pendapatan, kesehatan, pendidikan, dan sebagainya. Indeks Pembangunan Manusia (IPM) Provinsi Bali pada 2020 yang mencatatkan capaian sebesar 75,50 atau meningkat 0,12 poin dibanding tahun 2019 yang tercatat sebesar 75,38 . Selanjutnya dalam hal penduduk miskin mengalami fluktuatif dimana saat mengalami peningkatan tingkat penduduk miskin di Provinsi Bali terjadi ketidakmerataan atau ketimpangan.Jumlah penduduk miskin di Provinsi Bali tercatat meningkat menjadi $3,78 \%$ atau sekitar 165,19 ribu jiwa pada Maret 2020. Kemiskinan di daerah perdesaan lebih tinggi dari yang tinggal di kota, yaitu $4,78 \%$ di desa dan 3,33\% di kota.

Dengan demikian dalam uraian pembahasan kali ini akan lebih membahas mengenai Pengaruh Pembangunan Infrastruktur, Tingkat Kemiskinan dan Indeks Pembangunan Manusia terhadap Perumbuhan Ekonomi Provinsi Bali tahun 2015-2020, agar kita dapat mengetahui lebih dalam mengenai masalah pengaruh dari faktor-faktor tersebut terhadap pertumbuhan ekonomi di Provinsi Bali, sehingga kita dapat memberi solusi untuk mengatasi masalah yang ada. Dimana dalam hal ini erat kaitannya antara keberadaan jalan raya serta kontribusi pembangunan manusia dengan upaya peningkatan perekonomian di Kabupaten/kota Provinsi Bali sangat diperlukan untuk menunjang laju pertumbuhan ekonomi.

\section{Metode Penelitian}

Penggunaan studi empiris pada penelitian ini menggunakan data sekunder yang bersumber dari laporan Badan Pusat Statistik (BPS) Provinsi Bali. Peneliti menggunakan jenis data panel dengan periode tahun 2015-2020 data time series dan 9 Kabupaten/Kota di Provinsi Bali data cross section.

Metode analisis yang digunakan dalam penelitian ini adalah dengan melakukan analisis regresi informasi panel dengan menggunakan aplikasi Eviews 10. Analisis regresi utama mengkaji ketergantungan suatu variabel (yaitu ketergantungan suatu variabel terikat pada variabel lain, yaitu yang disebut Variabel Independen. dalam bahasa sehari-hari). Berdasarkan variabel-variabel yang telah dipaparkan oleh peneliti maka model regresi data panel empiris dirumuskan sebagai berikut :

$$
\begin{gathered}
\text { PEit }=\alpha+\beta 1 \mathrm{INFJit}+\beta 2 \mathrm{PMit}+ \\
\beta 3 \mathrm{IPMit}+\varepsilon i \mathrm{t}
\end{gathered}
$$

Dimana :
PE : Pertumbuhan Ekonomi
INFJ : Infrastruktur Jalan
PM : Penduduk Miskin
IPM : Indeks Pembangunan 


\begin{tabular}{|c|c|}
\hline & Manusia \\
\hline & : Banyaknya \\
\hline & $\begin{array}{l}\text { kota/kabupaten (data } \\
\text { cross section) }\end{array}$ \\
\hline $\mathrm{T}$ & $\begin{array}{l}\text { : Banyaknya tahun (dat } \\
\text { time series) }\end{array}$ \\
\hline & : error term \\
\hline
\end{tabular}

Untuk mengestimasi data panel diperlukan beberapa langkah terlebih dahulu sebelum menggunakan Common Effect, Fixed Effect, atau Random Effect yaitu dengan mengestimasi dari hasil terbaik menggunakan uji Chow yang digunakan untuk menentukan apakah model Common Effect lebih baik digunakan dari pada Fixed Effect dengan nilai probabilitas lebih keil dari derajat kepercayaan yang dipilih $(0,05)$, uji Hausman yang digunakan untuk menentukan apakah model Fixed Effect lebih baik digunakan dari pada Random Effect dimana apabila nilai probabilitas lebih kecil dari derajat kepercayaan $(0,05)$ maka model yang terbaik untuk dipilih yaitu Fixed Effect, dan Lagrange Multiplier test yang digunakan untuk menentukan apakah model Random Effect lebih baik digunakan dari pada Ordinary Least Square dimana apabila nilai probabilitas lebih besar dari chi-square.

\section{Hasil dan Pembahasan}

Melalui pengolahan data dari variabel-variabel yang telah dipaparkan oleh peneliti, maka diperoleh hasil penelitian sebagai berikut.

Tabel 1

Hasil Estimasi Model Regresi Data Panel

\begin{tabular}{lrrr}
\hline Variable & $\begin{array}{c}\text { Common } \\
\text { Effect }\end{array}$ & $\begin{array}{l}\text { Fixed } \\
\text { Effect }\end{array}$ & $\begin{array}{c}\text { Rando } \\
\boldsymbol{m} \\
\text { Effect }\end{array}$ \\
\hline C & 0.0000 & 0.0000 & 0.0000 \\
\hline $\begin{array}{l}\text { INF_JALA } \\
\text { N }\end{array}$ & 0.1320 & 0.0270 & 0.0557 \\
\hline PEND_MIS & & & \\
KIN & 0.9326 & 0.7714 & 0.9137 \\
\hline IPM & 0.0030 & 0.0004 & 0.0002 \\
\hline R-squared & 0.233799 & 0.624332 & 0.2337 \\
\hline
\end{tabular}

\begin{tabular}{lllr}
\hline & & & 99 \\
\hline $\begin{array}{l}\text { Adjusted R- } \\
\text { squared }\end{array}$ & 0.177735 & 0.499109 & 0.1777 \\
\hline $\begin{array}{l}\text { Prob(F- } \\
\text { statistic) }\end{array}$ & 0.011471 & 0.000155 & 35 \\
\hline Sumber & & & \\
\hline
\end{tabular}

Sumber: Hasil estimasi penulis, 2021

Dari hasil yang tertera, dapat dilihat bahwa dari pendekatan Common Effect, Fixed Effect dan Random Effect terdapat hasil yang berbeda-beda. Nilai R-squared pada uji Common Effect sebesar 0.233799, pada uji Fixed Effect sebesar 0.624332 dan pada uji Random Effect sebesar 0.233799. Setelah melakukan uji model yang akan digunakan selanjutnya yaitu dalam penelitian ini dilakukan estimasi pemilihan model mengunakan uji chow dan uji hausman.

\section{Uji Chow}

Tabel 2

\section{Hasil Regresi dengan Uji Chow}

\begin{tabular}{llll}
\hline Effect Test & Statistic & d.f. & Prob. \\
\hline $\begin{array}{l}\text { Cross- } \\
\text { section F }\end{array}$ & 4.288216 & $(8.33)$ & 0.0013 \\
\hline $\begin{array}{l}\text { Cross- } \\
\text { section }\end{array}$ & 32.073199 & 8 & 0.0001 \\
Chi-square & & & \\
\hline
\end{tabular}

Sumber: Hasil estimasi penulis, 2021

Berdasarkan tabel uji chow, nilai probabilitas cross-section chi square yang lebih kecil dari derajat kepercayaa $(0,05)$ yakni sebesar 0.0001. Maka hasil uji chow menolak pendekatan Common Effect model dan menerima pendekatan Fixed Effect model. Kemudian selanjutnya dilakukan regresi dengan pendekatan Random Effect model. Kemudian dilakukan uji hausman dengan hasil sebagai berikut.

\section{Uji Hausman}

Tabel 3

Hasil Regresi dengan Hausman Test

\begin{tabular}{|c|c|c|c|}
\hline \multicolumn{4}{|c|}{ Correlated Random Effects - Hausman Test } \\
\hline \multicolumn{4}{|c|}{ Equation: Untitled } \\
\hline \multicolumn{4}{|c|}{ Test cross-section Random Effects } \\
\hline $\begin{array}{l}\text { Test } \\
\text { Summary }\end{array}$ & $\begin{array}{l}\text { Chi-Sq. } \\
\text { Statistic }\end{array}$ & $\begin{array}{l}\text { Chi-Sq. } \\
\text { d.f. }\end{array}$ & Prob. \\
\hline $\begin{array}{l}\text { Cross- } \\
\text { section } \\
\text { random }\end{array}$ & 32.424808 & 3 & 0.0000 \\
\hline
\end{tabular}


Berdasarkan tabel uji hausman diatas, nilai probabilitas cross-section random adalah sebesar 0.0000 yang artinya lebih kecil dari alpha 0,05. Maka hasil uji hausman menolak pendekatan Random Effect model dan memilih Fixed Effect model. Maka model regresi terbaik yang digunakan dalam penelitian ini adalah model dengan pendekatan Fixed Effect model. Maka tidak dilakukan pengujian lanjutan untuk uji LM karena model terbaik sudah terpilih.

\section{Uji Asumsi Klasik}

Hasil olah yang diperoleh menggunakan bantuan Eviews 10 sebagai berikut :

Tabel 4 Hasil Estimasi Normalitas

\begin{tabular}{lr}
\hline \multicolumn{2}{l}{ Series : Standarized Residuals } \\
\hline \multicolumn{2}{l}{ Sample 2015 2019 } \\
\hline \multicolumn{2}{l}{ Observations 45 } \\
\hline Mean & $4.47 \mathrm{E}-18$ \\
\hline Median & -0.006829 \\
\hline Maximum & 0.076727 \\
\hline Minimum & -0.103269 \\
\hline Std. Dev. & 0.043448 \\
\hline Skewness & -0.462421 \\
\hline Kurtos is & 2.550406 \\
\hline Jarque-Bera & 1.98275 \\
\hline Probability & 0.371066
\end{tabular}

Sumber: Hasil estimasi penulis, 2021

Uji Normalitas bertujuan untuk menguji apakah dalam model regresi variabel dependen dan variabel independen keduanya mempunyai distribusi normal atau paling tidak mendekati distribusi normal. Berdasarkan hasil perhitungan dapat diketahui bahwa nilai probabilitas JarqueBera sebesar 1.982750 maka dengan probabilitas sebesar 0.371066 lebih besar dari tingkat signifikansi yang digunakan yaitu $\alpha=5 \%$ atau sebesar 0.05 dapat disimpulkan bahwa residual model regresi berdistribusi normal.

\section{Tabel 5}

Hasil Estimasi Multikolinearitas

\begin{tabular}{cccc}
\hline & $\begin{array}{c}\text { INF_JAL } \\
\text { AN }\end{array}$ & $\begin{array}{c}\text { PEND_MIS } \\
\text { KIN }\end{array}$ & IPM \\
\hline $\begin{array}{c}\text { INF_JAL } \\
\text { AN }\end{array}$ & 1.000000 & 0.063504 & -0.025469 \\
\hline $\begin{array}{c}\text { PEND_M } \\
\text { ISKIN }\end{array}$ & 0.063504 & 1.000000 & -0.110566 \\
\hline IPM & -0.25469 & -0.110566 & 1.000000
\end{tabular}

Sumber: Hasil estimasi penulis, 2021

Dengan koefisien antar variabel independen lebih besar dari 0,8 maka dapat dinyatakan bahwa terdapat masalah kolinearitas dalam model. Bahkan jika koefisien korelasi kurang dari 0,8, model tersebut tidak memiliki kolinearitas. Berdasarkan hasil yang telah tertera terlihat bahwa korelasi antar variabel independen jauh di bawah 0,8 yang berarti tidak terdapat multikolinearitas.

\section{Tabel 6}

\section{Hasil Estimasi Uji Heteroskedatisitas}

\begin{tabular}{|c|c|c|c|c|}
\hline $\begin{array}{c}\text { Variabl } \\
\text { e }\end{array}$ & $\begin{array}{c}\text { Coeffici } \\
\text { ent }\end{array}$ & $\begin{array}{c}\text { Std. } \\
\text { Error }\end{array}$ & $\begin{array}{c}\mathrm{t}- \\
\text { Statistic }\end{array}$ & Prob. \\
\hline $\mathrm{C}$ & $\begin{array}{c}0.08658 \\
2 \\
\end{array}$ & $\begin{array}{c}0.05173 \\
5\end{array}$ & $\begin{array}{c}1.67356 \\
5 \\
\end{array}$ & 0.1018 \\
\hline $\begin{array}{c}\text { INF_JA } \\
\text { LAN }\end{array}$ & $\begin{array}{c}-1.37 \mathrm{E}- \\
05\end{array}$ & $\begin{array}{c}\text { 7.37E- } \\
06\end{array}$ & $\begin{array}{c}- \\
1.86669 \\
8\end{array}$ & 0.0691 \\
\hline $\begin{array}{c}\text { PEND_ } \\
\text { MISKI } \\
\mathrm{N}\end{array}$ & $\begin{array}{c}- \\
0.00039 \\
0\end{array}$ & $\begin{array}{c}0.00044 \\
9\end{array}$ & $\begin{array}{c}- \\
0.86823 \\
0\end{array}$ & 0.3903 \\
\hline IPM & $\begin{array}{c}- \\
0.00050\end{array}$ & $\begin{array}{c}0.00067 \\
7\end{array}$ & $\begin{array}{c}- \\
0.74499\end{array}$ & 0.4605 \\
\hline
\end{tabular}

Sumber: Hasil estimasi penulis, 2021

Uji ini bertujuan untuk melihat ada tidaknya variansi di dalam data. Dari hasil olah di atas, dapat diketahui dimana nilai $\mathrm{p}$ value yang ditunjukkan dengan nilai Probabilitas lebih besar dari derajat kepercayaan $(0,05)$, maka menerima $\mathrm{H} 0$ atau berarti model tersebut terbebas dari heteroskedastisitas dengan kata lain bahwa model regresi memiliki varian residual tetap (homoskedastisitas). 
Tabel 7

Hasil Estimasi dengan Uji Autokorelasi

\begin{tabular}{cccc}
\hline \multicolumn{4}{c}{ Cross-section fixed (dummy variables) } \\
\hline \multicolumn{4}{c}{ Weighted Statistics } \\
\hline R-squared & 0.624322 & $\begin{array}{c}\text { Mean } \\
\text { dependent } \\
\text { var }\end{array}$ & 1.765536 \\
& \multicolumn{3}{c}{$\begin{array}{c}\text { S.D. } \\
\text { dependent } \\
\text { var }\end{array}$} \\
\hline $\begin{array}{c}\text { Adjusted } \\
\text { R-squared }\end{array}$ & 0.499109 & 0.070888 \\
& & $\begin{array}{c}\text { Sum } \\
\text { squared } \\
\text { resid }\end{array}$ & 0.083061 \\
\hline $\begin{array}{c}\text { S.E. of } \\
\text { regression }\end{array}$ & 0.050170 & $\begin{array}{c}\text { Durbin- } \\
\text { Watson } \\
\text { stat }\end{array}$ & 2.964588 \\
\hline F-statistic & 4.985765 & & \\
& & &
\end{tabular}

Prob(F- 0.000155

statistic)

Sumber: Hasil estimasi penulis, 2021

Uji ini bertujuan untuk mengetahui apakah dalam variabel terdapat autokorelasi. Dapat dilihat melalui nilai Durbin Watson (DW) dimana berdasarkan hasil penelitian menunjukkan nilai Durbin Watson sebesar 2.964588, dimana dL berarti sebesar 0,6291 dan dU sebesar 1,6993 yang berarti bahwa d $>$ dL dimana terdapat autokorelasi.

\section{Koefisien Determinasi (R2)}

Koefisien determinasi berguna untuk mengukur kemampuan model dalam menerangkan himpunan veriabel independen. Nilai koefisien determinasi ditunjukkan dengan angka antara nol sampai satu. Nilai determinan yang kecil berarti kemampuan variabel-variabel independen dalam variasi variable dependen amat terbatas. Sedangkan nilai yang mendekati satu berarti variabel-variabel independen tersebut memberikan informasi yang dibutuhkan untuk memprediksi variabel dependen.

Tabel 8

\section{Weighted Statistic}

\begin{tabular}{ll}
\hline R-squared & 0.624332 \\
\hline Adjusted R-squared & 0.499109 \\
\hline F-statistic & 4.985765 \\
\hline Prob(F-statistic) & 0.000155 \\
\hline
\end{tabular}

Sumber: Hasil estimasi penulis, 2021

Berdasarkan hasil estimasi regresi data panel dengan metode Fixed Effect, diperoleh nilai R-square (R2) sebesar 0.624332 yang menunjukkan bahwa kontribusi variabel independent yang terdiri dari infastruktur jalan, penduduk miskin, dan Indeks Pembangunan Manusia (IPM) mempengaruhi variabel dependent yaitu pertumbuhan ekonomi sebesar 62,43 persen saja dan sisanya 37,57 persen dipengaruhi oleh variabel lain di luar model penelitian ini.

\section{Uji F}

Uji ini untuk melihat kesignifikansian dari model yang dimiliki. Yang dilihat adalah nilai F-Statistik dan prob(F-Statistik) pada hasil uji regresi. Dari hasil pengujian data diketahui nilai probabilitas F-statistik 4.985765 dengan nilai f hitung (Prob FStatistik) sebesar 0.000155 (signifikan pada $\alpha 1 \%$ ). Dari hasil uji di atas artinya bahwa variabel infrastruktur jalan, penduduk miskin, dan indeks pembangunan manusia untuk sembilan kabupaten/kota di Provinsi Bali secara bersama-sama mempengaruhi laju pertumbuhan ekonomi secara signifikan pada tingkat kepercayaan 95\%. Maka model ini telah memenuhi goodness of fit atau uji kelayakan

Uji Parsial (Uji t)

Tabel 9

\begin{tabular}{|c|c|c|c|c|}
\hline \multicolumn{5}{|c|}{ Hasil Estimasi Uji Parsial (Uji t) } \\
\hline $\begin{array}{c}\text { Variabl } \\
\text { e }\end{array}$ & $\begin{array}{c}\text { Coeffici } \\
\text { ent }\end{array}$ & $\begin{array}{c}\text { t- } \\
\text { Statist } \\
\text { ic }\end{array}$ & Prob & Hasil \\
\hline $\begin{array}{c}\text { Infrastr } \\
\text { uktur } \\
\text { Jalan }\end{array}$ & $\begin{array}{l}5.25 \mathrm{E}- \\
05\end{array}$ & $\begin{array}{l}2.3137 \\
93\end{array}$ & 0.0270 & $\begin{array}{l}\text { Berpeng } \\
\text { aruh } \\
\text { positif, } \\
\text { signifik } \\
\text { an }\end{array}$ \\
\hline $\begin{array}{l}\text { Pendud } \\
\text { uk } \\
\text { Miskin }\end{array}$ & $\begin{array}{l}0.00213 \\
6\end{array}$ & $\begin{array}{l}0.2929 \\
15\end{array}$ & 0.7714 & $\begin{array}{l}\text { Berpeng } \\
\text { aruh } \\
\text { positif, } \\
\text { tidak } \\
\text { signifik } \\
\text { an }\end{array}$ \\
\hline $\begin{array}{c}\text { Indeks } \\
\text { Pemban } \\
\text { gunan } \\
\text { Manusi } \\
\text { a }\end{array}$ & $\begin{array}{l}0.05589 \\
3\end{array}$ & $\begin{array}{l}3.8972 \\
93\end{array}$ & 0.0004 & $\begin{array}{c}\text { Berpeng } \\
\text { aruh } \\
\text { negatif, } \\
\text { signifik } \\
\text { an }\end{array}$ \\
\hline
\end{tabular}

Sumber: Hasil estimasi penulis, 2021 
Nilai probailitas t-statistic digunakan untuk menguji hipotesis, terlihat pada variabel infrastruktur jalan (X1) dengan nilai uji t sebesar 2.313793 memiliki nilai prob t-statistic sebesar $0.0270<0.05$ dimana hal ini menunjukkan bahwa variabel infrastruktur jalan berpengaruh positif signifikan terhadap nilai laju pertumbuhan ekonomi. Artinya setiap kenaikan $1 \%$ infrastruktur jalan maka laju pertumbuhan ekonomi Kabupaten/Kota di Provinsi Bali akan mengalami kenaikan sebesar 5,25 persen. Dengan adanya infrastruktur jalan terlebih dengan pembangunan jalan tol di Provinsi Bali yang akan melintasi beberapa desa atau kabupaten memberikan dampak positif untuk masyarakat dalam pemerataan pembangunan sebagai pertumbuhan perekonomian dan peningkatan kas negara. Selain itu juga, jalan ini akan menjadi pilihan alternatipe dalam mengurangi jarak tempuh, waktu dan kemacetan perjalanan. Hal ini sejalan dengan penelitian (Lianna \& Anshar, 2020) dimana secara parsial dengan hasil regresi variabel infrastruktur jalan belum berpengaruh signifikan terhadap PDRB Kabupaten/Kota di Provinsi Kalimantan Selatan dikarenakan permasalahan yang dihadapi dalam pengembangan jalan antara lain belum optimalnya pengendara jalan dalam mempergunakan jalan dengan sebaikbaiknya, jalan dalam kondisi rusak diakibatkan banyaknya mobil-mobil besar yang lalu lalang melewati jalan tanpa aturan.

Pada variabel penduduk miskin (X2) memiliki nilai probabilitas t-statistic sebesar 0.7714>0.05 dengan nilai uji $t$ senilai 0.292915 , dimana hal ini ternyata penduduk miskin berpengaruh secara positif namun tidak signifikan terhadap laju pertumbuhan ekonomi. Pertumbuhan ekonomi tetap terjadi meskipun kemiskinan juga meningkat dikarenakan dalam kegiatan ekonomi, factor produksi disinergikan untuk menciptakan nilai tambah dimana minimnya akses penduduk miskin terhadap factor produksi menyebabkan akses terhadap nilai tambah juga minim. Hal ini sejalan dengan penelitian (Adelowokan et al., 2019) Studi ini menunjukkan bahwa meskipun ada populasi miskin yang ditentukan oleh angka absolut, output suatu negara akan meningkat. Meskipun jumlah penduduk miskin meningkat, perekonomian akan terus tumbuh. Juga dalam jangka pendek, meskipun jumlah penduduk miskin meningkat dari tahun ke tahun, perekonomian tetap tumbuh. Perlu adanya kebijakan makroekonomi yang stabil untuk menjamin pemerataan pendapatan sehingga masyarakat miskin juga mendapat manfaat dari pertumbuhan Negara.

Pada variabel indeks pembangunan manusia (X3) memiliki nilai probabilitas tstatistic sebesar $0.0004<0.05$ dengan nilai uji t senilai -3.897293, yakni koefisien indeks pembangunan manusia bertanda negative yang berarti berpengaruh negative dan signifikan terhadap laju pertumbuhan. Artinya setiap kenaikan 1 persen indeks pembangunan manusia maka laju pertumbuhan Kabupaten/Kota di Provinsi Bali akan mengalami penurunan sebesar 0,05 persen. Pada variabel ini memberikan hasil yang tidak sejalan dengan teori IPM yang seharusnya IPM berpengaruh positif terhadap laju pertumbuhan ekonomi. Terdapat factor lain dimana perekonomian yang baik tidak berkorelasi dengan kualitas sumber daya manusia dikarenakan Provinsi Bali masih didominasi 21 hingga 27 persen masyarakat dengan lulusan sekolah dasar saja. Bahkan apabila digabungkan dengan masyarakat yang tidak memiliki ijazah berada di angka 14 hingga 19 persen, maka penduduk kurang berpendidikan di Provinsi Bali dapat berkisar 43 persen dari total penduduk. Masalah utama Pemerintah untuk memajukan dan mendorong kualitas sumber daya manusia Bali terletak pada mentalitas 
masyarakatnya dimana dengan kemajuan teknologi yang pesat menjadikan adanya mentalitas manja yang enggan berpendidikan tinggi dan enggan bekerja keras. Ditambah dengan adanya pandemic Covid -19 menyebabkan menurunnya kemampuan masyarakat dalam memenuhi kebutuhan hidupnya, yang digambarkan oleh komponen rata-rata pengeluaran per kapita disesuaikan (PPP) yang tercatat sebesar Rp13,93 juta rupiah menurun Rp217.000 dari tahun sebelumnya. Penelitian ini sejalan dengan (Handayani et al., 2017) yang menyatakan bahwa variabel IPM memiliki korelasi yang negative namun berpengaruh signifikan terhadap PDRB Kabupaten/kota di Provinsi Sumatera Selatan. Namun penelitian ini berbeda dengan (Asnidar, 2018) yang menyatakan bahwa tingkat IPM berpengaruh positif tidak signifikan terhadap pertumbuhan ekonomi di Kabupaten Aceh Timur dikarenakan setiap daerah ingin memaksimalkan kualitas sumber daya manusia yang memadai untuk dapat meningkatkan pembangunan dan mensejahterakan masyarakat.

\section{Kesimpulan}

$$
\begin{aligned}
& \text { Berdasarkan hasil estimasi regresi } \\
& \text { untuk pemilihan model terbaik } \\
& \text { menggunakan uji Chow dan uji Hausman, } \\
& \text { pada data panel terpilih model terbaik yang } \\
& \text { digunakan dalam penelitian yakni Fixed } \\
& \text { Effect (FEM). Dalam uji koefisien } \\
& \text { determinasi (R2) seluruh variabel yang } \\
& \text { digunakan meliputi variabel infrastruktur } \\
& \text { jalan, penduduk miskin, dan indeks } \\
& \text { pembangungan manusia terhadap laju } \\
& \text { pertumbuhan ekonomi sembilan } \\
& \text { kabupaten/kota di Provinsi Bali } \\
& \text { menunjukkan hasil sebesar 62,43 persen } \\
& \text { dipengaruhi oleh variabel-variabel bebas } \\
& \text { yang peneliti tentukan dalam model regresi } \\
& \text { data panel metode Fixed Effect. Sementara } \\
& \text { sisanya sebesar 37,57 persen dijelaskan oleh }
\end{aligned}
$$

variabel-variabel lain diluar model penelitian ini. Secara parsial variabel infrastruktur jalan memiliki pengaruh positif dan signifikan terhadap laju pertumbuhan ekonomi. Hal ini dikarenakan pada setiap kenaikan infrastruktur jalan diiringi dengan kenaikan laju pertumbuhan ekonomi Kabupaten/Kota di Provinsi Bali. Sedangkan untuk variabel penduduk miskin secara parsial memiliki pengaruh yang positif namun tidak signifikan terhadap laju pertumbuhan ekonomi. Hal ini dikarenakan apabila setiap kenaikan penduduk miskin diiringi dengan kenaikan laju pertumbuhan ekonomi Kabupaten/Kota di Provinsi Bali. Secara parsial variabel Indeks Pembangunan Manusia (IPM) memiliki pengaruh negative dan signifikan terhadap laju pertumbuhan ekonomi.

\section{BIBLIOGRAFI}

Adelowokan, O. A., Maku, O. E., Babasanya, A. O., \& Adesoye, A. B. (2019). Unemployment, poverty and economic growth in Nigeria. Journal of Economics \& Management, 35, 517. Google Scholar

Ali, M. (2009). Pendidikan untuk pembangunan nasional: menuju bangsa Indonesia yang mandiri dan berdaya saing tinggi. Grasindo. Google Scholar

Asnidar. (2018). Pengaruh Indeks Pembangunan Manusia ( IPM ) dan Inflasi terhadap Pertumbuhan Ekonomi di Kabupaten Aceh Timur. 2(1), 1-12. Google Scholar

Damayanthi, V. R. (2008). Proses industrialisasi di Indonesia dalam prespektif ekonomi politik. Journal of Indonesian Applied Economics, 2(1). Google Scholar

Ilham, R., Ap, S., Ramawi, D. H. M. A. T., \& Si, M. (2021). Pembangunan Infrastruktur Dikota Sungai Penuh 
Analisis Pengaruh Infrastruktur, Tingkat Kemiskinan dan Indeks Pembangunan Manusia terhadap Pertumbuhan Ekonomi Provinsi Bali 2015-2020

Tahun 2019. 3(3), 18-29. Google Scholar

Lianna, L. D. R. D., \& Anshar, M. (2020). Pengaruh Infrastruktur Terhadap Pdrb Kabupaten/Kota Di Provinsi Kalimantan Selatan Tahun 20142018. Jurnal Syntax Transformation, 1(7), 328-334. Google Scholar

Utama, G. I. (2020). BKD 2019-2.Google Scholar

Iriyena, P. (2019). Analisis Pengaruh Infrastruktur Jalan Terhadap Pertumbuhan Ekonomi Di Kabupaten Kaimana 2007-2017. Jurnal Berkala Ilmiah Efisiensi, 19(02), 49-59. Google Scholar

Jonaidi, A. (2012). Analisis Pertumbuhan Ekonomi dan Kemiskinan. Kajian Ekonomi, 1(April), 140-164. Google Scholar

Kustanto, A. (2020). Pertumbuhan Ekonomi Regional di Indonesia: Peran Infrastruktur, Modal Manusia dan Keterbukaan Perdagangan (Regional Economic Growth in Indonesia: The Role of Infrastructure, Human Capital and Trade Openness). Buletin Studi Ekonomi, 25(1). Google Scholar

Mankiw, N. G. (2006). Teori Makroekonomi Edisi Keenam. Jakarta: Erlangga. Google Scholar
Mirza, D. S. (2012). Pengaruh kemiskinan, pertumbuhan ekonomi, dan belanja modal terhadap indeks pembangunan manusia di Jawa Tengah tahun 20062009. Economics Development Analysis Journal, 1(2). Google Scholar Prasetyoningrum, A. K., \& Sukmawati, U. S. (2018). Analisis Pengaruh Indeks Pembangunan Manusia (IPM), Pertumbuhan Ekonomi dan Pengagguran Terhadap Kemiskinan di Indonesia. Equilibrium: Jurnal Ekonomi Syariah, 6(2), 217-240. Google Scholar

Resalawati, A. (2011). Pengaruh perkembangan usaha kecil menengah terhadap pertumbuhan ekonomi pada sektor UKM di Indonesia. Google Scholar

Susanto, A. B. (2013). Pengaruh Indeks Pembangunan Manusia (IPM) dan Inflasi Terhadap Pertumbuhan Ekonomi di Kabupaten Lamongan. Jurnal Pendidikan Ekonomi (JUPE), 1(3). Google Scholar

Tino Handayani. (2019). Pengaruh Belanja Modal, Infrastruktur dan Indeks Pembangunan Manusia terhadap Produk Domestik Regional Bruto di Provinsi Sumatera Selatan. Jurnal Ekonomi Pembangunan, 15(2), 92100. Google Scholar

Copyright holder :

Risthi Khoirunnisa Wadana, Whinarko Juli Prijanto (2021).

First publication right :

Jurnal Syntax Transformation

This article is licensed under: 